\title{
The Practice of Business English Cooperative Learning in the Network Environment
}

\author{
Lu Sun \\ Harbin University of Commerce, Harbin, China, 150028 \\ SUN_LU1980@163.com
}

Keywords: Business English; Cooperative learning; Network environment; Constructivism;

\begin{abstract}
Business English Cooperative Learning in network environment is an important development direction of business English teaching. This paper analyzes the network environment and the theoretical basis of cooperative learning, and focuses on the application of several cooperative learning methods in Business English teaching.
\end{abstract}

\section{Introduction}

The Ministry of education in January 2004 was officially launched "College English Curriculum Requirements (for Trial Implementation)" pointed out: "we should make full use of multimedia and network technology development has brought the opportunity and the new teaching mode to improve the original to teachers in the teaching dominated by a single classroom teaching mode, English Teaching towards personalized learning, not subject to the constraints of time and place of learning. This highlights the importance of modern science and technology - the Internet in College English teaching. At the same time further noted that "should fully mobilize the enthusiasm of both teachers and students", "should pay attention to teachers' face-to-face counseling effect" and "new teaching mode in technology should be embodied interaction, and ease of use". This reflects the personalized learning to through the guiding role of teachers, language learning is inseparable from the people of mutual cooperation, namely "cooperative learning" (collaborative learning), its main approach is put the students in small groups to complete a common learning objectives. Therefore, College English teaching based on Network Environment

The implementation of learning is an important development trend in the process of College English teaching reform. In order to meet the needs of China's social development and international communication, to promote the reform of business English teaching and to carry out the concept of modern education, the concept of the Ministry of education should be embodied in the teaching of business English.

\section{The Network Environment}

The learning environment of the students in the network environment includes the organization environment, the resource environment and the hardware environment. The organization environment refers to the division of the cooperative group, the assignment of the members of the group, the mode of cooperation, etc. In the division of the group, according to the student's academic performance, knowledge structure, cognitive approach, the general use of complementary forms to help improve the effectiveness of cooperative learning. Resources and environment can be provided for students in the campus network, but this is limited to only students on campus cooperation learning, can also use virtual technology to build the Internet site of the corresponding, even if students do not at school, at home, or in other cities can also be to continue through the Internet and team / group cooperative learning. Hardware environment CSCW (Supported Cooperative Work Computer), which is a computer supported cooperative work and WWW based collaborative learning. CSCW is a kind of the human cooperation mode with computer technical support fusion is one of the emerging technology that is based on computer technology support environment (CS) a group cooperative work completed a common task (CW). 


\section{On Cooperative Learning}

Cooperative learning is a learning method which is based on the theory of constructivism, which refers to the way that the students cooperate in the form of group in order to achieve the common learning objectives. Constructivism was developed on the basis of cognitivism unique learning concept, it considers "learning should not be viewed as passive acceptance of the teachers to give knowledge of the learners, but to their existing knowledge and experience is based on active construction activity". That is to say, students learning process is in the context of the creation of teachers, with the existing knowledge and experience, active exploration, active communication, so as to establish a new cognitive structure of the process. It maintains that learning is a process of learning to construct their own knowledge and experience. It is a process of enriching, enriching and reforming the existing knowledge and experience through the interaction of new experience and knowledge experience. In the process of constructivism teaching, students learning, unlike traditional teaching view think that is a relatively isolated individual competition behavior, and mainly through the mutual cooperation between teachers and students, between students gradually completed. So it requires the organizer teaching according to the teaching content carefully design each learning task, let learners through group discussion, learn from each other, promote each other, sharing learning materials, give full play to the team member's enthusiasm, active, creative and mutual, to jointly complete the scheduled task or solve a problem.

Theory and practice of cooperative learning applied in foreign countries has long been, according to David W. Johnson and Roger T. Johnson social interdependence theory, cooperative learning contains five basic elements: positive interdependence (more positive), beneficial interaction (in vitro interaction) and personal responsibility Individual Accountability), social (social skills) skills, group processing (group) processing. According to the theory, the learners participate in the group, in order to achieve the common goal of learning, in a certain incentive mechanism to obtain the maximum individual and group learning achievements and cooperation and mutual assistance.

\section{The Implementation of Business English Cooperative Learning in the Network Environment}

So-called under the network environment based cooperative learning refers to the use of computer network and multimedia technology, teachers to the students explain learning content, between teachers and students, between students and students can have a learning content to carry out online discussion and exchange information with each other, in order to achieve the teaching content more profound understanding and grasp. In the use of the network of collaborative learning, both human-computer interaction, but also the interaction between people. Cooperative learning in the network is a kind of learning process, which is not restricted by place and time, and can get online help and information resources at any time in the course of learning. This study is usually to group learning, which is the central link of the network cooperative learning, group learning in the form of a variety of forms, such as competition, discussion, collaboration, problem solving, partners, design and role plays. Below, we mainly discuss the implementation of several kinds of business English Teaching:

Competition and Cooperation. Competition type is the two or more learners for the same learning content, through the network of competitive learning. In this form, learners pay more attention to the competition with other learners rather than cooperate with them. Teachers set up learning objectives and learning content in the computer learning system, and provide relevant information to the learners to solve the problem. Learners can choose a competitor from the online list of online learners, and negotiate a good agreement, and then start to solve the problem independently, to see who will complete the task. The competition form of cooperative learning is conducive to stimulate students' learning confidence and morale, and enhance the learning initiative and enthusiasm of the learners. If it is competition between individual learning, learners can understand and learn from the opponent's learning process, promote their learning activities, 
improve the learning skills; if it is between group competition learning, encourage all team members to redouble their efforts to, close cooperation, so as to win the better team performance.

Discuss Collaboration Type. Discussion groups are generally 5 - 3 people, the number of people will make it difficult to control the discussion, it will make the learners lose interest; the number is too small, the task is too heavy, the amount of information is not enough. Through the network, the cooperation group members can choose freely, free combination, and for the teacher put forward some problems to discuss, negotiation, and finally reach the consensus on the issue. In the process of problem solving, the cooperative researchers can access a large amount of data by means of virtual library or network, to provide basis and material for solving problems. The final outcome of the discussion may be a report, courseware presentation, or a small paper. In order to make your team to get better grades, group members between together, ideas, make each student's personal self-esteem, self-confidence and team honor sense naturally into the learning motivation and passion. At the same time, it plays an important role in training and improving learners' ability to deal with and solve problems.

Partner Collaboration Type. Study group composed of two people, the learners to complete a learning task to form partnerships, partners on issues of common concern for discussion and consultation and from each other trying to get ideas and inspiration to solve the problem, also for learning each other mutual inspection, to help each other. The cooperative learning in the form of characteristic is: by the learners themselves to find collaborators, learners is usually the first choice their own learning content, then through the network to find the same content of other learners in the learning, choose one of the learners, by mutual consent, for learning group with. Of course, learning partners can be a learner, can also act as a computer. Partners can enable collaborative learning in a more harmonious atmosphere, can make learners in learning feel there has been a partner can support and help each other, once the problems, feel free to get in touch with each other and it is good for cooperative learning.

Role Reversal. The group is made up of two people. Discrimination and analysis they were served as learning and leading role, learner for answering questions, and guide is to answer, when learners have encountered difficulties in the problem solving process, by the guidance to help learners to solve difficult. In cooperative learning, the roles they play can be exchanged. Through role play, each learner's understanding of the problem will enter a new level. Role playing success will increase the sense of achievement and responsibility, but also stimulate the interest of learners to master the knowledge. The above four kinds of group learning form is the basic form of network cooperative learning, and can be flexibly selected and used according to the situation in practical cooperative learning, so as to achieve the best learning effect.

\section{Conclusion}

In the implementation of cooperative learning in English teaching, the learners feel that the students are no longer competitors, but to promote the help of learning. Cooperative learning can promote learners to actively participate in the learning process, effectively stimulate learners' interest in learning, to fully mobilize the enthusiasm of the learners as the subject of cognition of initiative and enthusiasm, so that the learner's learning activities more lively and colorful.

\section{Acknowledgements}

This paper is supported by Philosophy and Social Scientific Research Project Foundation of Heilongjiang Province (No.14C009). At the same time this paper is supported by the Higher Education Reform Project （No.JG2014010815） of Heilongjiang Province.

\section{References}

[1] Avery. G. C, Leadership for Sustainable Futures Achieving Success in a Competitive World, first ed, Edward Elgar, 2013. 
[2] Bacon. C. S, Enhancing Critical Thinking Skills through Conversation in the Classroom, J.Sci.Commun.11 (2011) 178-179.

[3] Cottrell. S, Critical Thinking Skills: Developing Effective Analysis and Argument, first ed., American Irwin, 2012.

[4] Cowen. T, Creative Destruction: How Globalization is changing the World's Cultures, first ed., Princeton University Press, 2012.

[5] Elsa Dent, The Leadership Pocketbook, first ed., Management Pocketbooks, 2003.

[6] Michalak. S. J, Liberal Education, J.Sci.Commun.156 (2013) 78.

[7] Quilliam. S. Positive Thinking, third ed., United States: DK Publishing, New York, 2012.

[8] Stamm. B. V, Managing, Innovation, Design, and Creativity, third ed., John Wiley \& Sons Ltd, Washington, 2013.

[9] Taylor. W. M, Informal Logic, J. Sci. Commun.10 (2012) 19-22.

[10]Thompson. J. N, On Being a Successful Graduate Student, first ed., University of California, 2011. 